\title{
A study of the influence of newly synthesized acyclonucleo- sides and 1,2,3,4-tetrahydroisoquinoline derivatives on deoxythymidine and deoxycytidine kinase activities in human neurofibrosarcoma and ovarian cancer
}

\author{
Hanna Modrzejewska ${ }^{1}$, Elżbieta Brzezińska ${ }^{2}$, Marcin Dramiński ${ }^{3}$, Anna \\ Zgit-Wróblewska ${ }^{3}$, Katarzyna Krzykowska ${ }^{1}$, Elżbieta Rozpończyk ${ }^{1}$ and \\ Janusz Greger ${ }^{1 凶}$
}
${ }^{1}$ Department of Medical Biochemistry, Institute of Physiology and Biochemistry, Medical University of Łódż, Eódż, Poland, ${ }^{2}$ Institute of Chemistry and Technology of Drugs, Medical University of Łódż, Eódż, Poland, ${ }^{3}$ Department of General Chemistry, the Ludwik Rydygier Medical University of Bydgoszcz, Bydgoszcz, Poland

Reeceived: 17 September, 2002; revised: 30 July, 2003; accepted: 19 August, 2003

Key words: acyclonucleosides, 1,2,3,4-tetrahydroisoquinoline, deoxynucleoside kinases

\begin{abstract}
The influence of nine newly synthesized uracil acyclonucleosides, and 36 derivatives of 1,2,3,4-tetrahydroisoquinoline on the activity of enzymes catalysing dTMP and dGMP synthesis, on the content of dTTP and dGTP in acid soluble fraction and on the incorporation of $\left[{ }^{14} \mathrm{C}\right] \mathrm{dTh}$ and $\left[{ }^{14} \mathrm{C}\right] \mathrm{dGuo}$ into DNA in tumour homogenates was studied. The influence of the compounds was studied in the cytosol from intraoperatively excised human tumours - neurofibrosarcoma and ovarian cancer.

It was shown that dTMP and dGMP synthesis is inhibited competitively by $34.1 \pm 4.0 \%$ in both types of tumours by $0.2 \mathrm{mM} 1-\mathrm{N}$-(3'-hydroxypropyl)-6-methyluracil (1) and $0.2 \mathrm{mM}$ 1-N-(3'-hydroxypropyl)- 5,6- tetramethyleneuracil (2). The mentioned acyclonucleosides reduced the content of dTTP and dGTP in the acid soluble fraction of tumours $(59.7 \pm 3.1 \%$ of control). 1-(4-chlorophenyl)-6,7-dihydroxy1,2,3,4-tetrahydroisoquinoline (3), 1-(2,3-dichlorophenyl)-6,7-dihydroxy 1,2,3,4-tetrahydroisoquinoline (4) and 1-(3-methoxyphenyl)-6,7-dihydroxy 1,2,3,4-tetrahydroisoquinoline (5) at $0.2 \mathrm{mM}$ concentration caused a mixed type inhibition of the synthesis of dTMP and dGMP by, on average, $33.2 \pm 4.4 \%$, and reduced the content of dTTP and dGTP in the acid soluble fraction $(52.6 \pm 3.7 \%$ of control) but were active only in the cytosol of neurofibrosarcoma. While acyclonucleosides undergo
\end{abstract}

\footnotetext{
${ }^{凶}$ Department of Medical Biochemistry, Institute of Physiology and Biochemistry, Medical University of Łódź, Mazowiecka 6/8, 92-215 Łódź, Poland; phone/fax: (48 42) 6782465.

Abbreviations: ACN, acyclonucleoside; HMDS, hexamethyldisilazane; THI, tetrahydroisoquinoline.
} 
phosphorylation in the cytosol by cellular kinases, with their triphosphates being active acyclonucleoside metabolites, active 1,3,4,5-tetrahydroisoquinoline derivatives (compounds not containing a deoxyribose moiety), cannot be phosphorylated. ACN and THI derivatives which inhibit dThd and dCyd kinase activities, inhibit also the incorporation of $\left[{ }^{14} \mathrm{C}\right] \mathrm{dTh}$ Thd $\left[{ }^{14} \mathrm{C}\right] \mathrm{dGuo}$ (ACN $-50.2 \pm 2.7 \%$, THI $-53.4 \pm 3.9 \%$ of incorporation inhibition) into tumour DNA. The obtained results point to the mechanism of uracil acyclonucleosides and 1,2,3,4-tetrahydroisoquinoline biological activity consisting in inhibiting the synthesis of DNA components.

In this paper we present a continuation of our study on compounds exhibiting cytostatic properties. Previously we have found that alkoxymethyl purine and pyrimidine acyclonucleosides tested on experimental tumours (Kirkman-Robbins hepatoma, amelanotic melanoma) inhibit tumour growth, the synthesis of dAMP, dGMP and dTMP, and the incorporation of dNTP into DNA (Greger \& Dramiński, 1989; Modrzejewska et al., 1996; 1999). The results presented herein concern 45 newly synthesized compounds. Nine of them are acyclonucleoside (ACN) uracil derivatives and 36 are tetrahydroisoquinoline (THI) derivatives. The inclusion of THI derivatives has resulted from the fact that these compounds, apart from other properties, exhibit also cytostatic activity (Lin M-C et al., 1995; Goldbrunner et al., 1997). Among the investigated compounds two ACN derivatives (Fig. 1, comp. 1, 2) and three THI derivatives (Fig. 1, comp. 3, 4 and 5) reveal moderate biological activity. Compounds 6 and 7 are hardly biologically active; the reason of their inclusion in the study will be explained in the Results and Discussion. The study on the biological properties of the ACN and THI derivatives were carried out on intraoperatively obtained human tumours - neurofibrosarcoma and ovarian cancer. Determination of dTMP synthesized by dThd kinase enabled the assessment of this enzyme activity. dGMP synthesis served to evaluate dCyd kinase activity, as dGuo and not dCyd is the preferred substrate of this enzyme (Usova \& Eriksson, 1997). dGuo kinase occurs mainly in mitochondria (Wang et al., 1993; Jullig \& Eriksson, 2001) dCyd kinase is responsible for the synthesis of dGMP in the cytosol (Arner \& Eriksson, 1995). Apart from the determina- tion of the activities of both kinases which were subject to the effect of active forms of ACNs and THIs, we studied the content of dTTP and dGTP in the acid soluble fraction obtained from tumour homogenates, the phosphorylation of ACNs and THIs catalysed by kinases present in the cytosol of the tumours and also the incorporation of $\left[{ }^{14} \mathrm{C}\right] \mathrm{dThd}$ and $\left[{ }^{14} \mathrm{C}\right] \mathrm{dGuo}$ into DNA obtained fom both tumours in the presence of ACN and THI. The aim of the latter study was to explain what products of ACNs and THIs biotransformation are responsible for their biological activity.

\section{MATERIALS AND METHODS}

Chemistry. $\left[{ }^{14} \mathrm{C}\right] \mathrm{dTh}$ and $\left[\gamma_{-}{ }^{32} \mathrm{P}\right] \mathrm{ATP}$ were obtained from Amersham (Buckinghamshire, England); [ $\left.{ }^{14} \mathrm{C}\right] \mathrm{dCyd},\left[{ }^{14} \mathrm{C}\right] \mathrm{dGuo}$, unlabeled $\mathrm{dCyd}$, dGuo and ATP were purchased from Sigma Chemical Company (St. Louis Mo, U.S.A.). Other reagents used were products of highest quality commercially available from Aldrich Chemical Company (Milwaukee, U.S.A.) Boehringer (Mannheim, Germany) Fluka A.G., Loba Chemie (Vienna, Austria) and Polskie Odczynniki Chemiczne (Gliwice, Poland).

1-N-(3'-hydroxypropyl)-6-methyluracil (1): 6-methyluracil $2.52 \mathrm{~g}(20 \mathrm{mmol})$ in $25 \mathrm{~cm}^{3}$ hexamethyldisilazane (HMDS) was refluxed for $3 \mathrm{~h}$ to dissolve uracil. The solvent was evaporated to viscous oil and equimolar amount of 1-benzyloxy-3-chloropropane was added. The mixture was kept overnight at room temperature. The reaction was monitored by TLC and the mixture was coevaporated with ethanol and with ammonia so- 
lution in ethanol. The residue was crystallised twice from ethanol. The yield of $1-N$-(3'-hydroxypropyl)-6-methyluracil was $1.5 \mathrm{~g}(45 \%)$.

1-N-(3'-hydroxypropyl)-5, 6-tetramethyleneuracil (2): 5,6-tetramethyleneuracil (3.32 g, 20 mmol) in $25 \mathrm{~cm}^{3}$ HMDS was refluxed for $3 \mathrm{~h}$ to dissolve uracil. In a similar manner as above the yield of 1-N-(3'-hydroxypropyl)-5,6-tetramethyleneuracil was $1.8 \mathrm{~g}$ (40\%).

3-N-(3'-hydroxypropyl)-5, 6-tetramethylene-2-th io uracil (6): a mixture of 10 mmoles sodium methanolate in methanol [prepared by dissolving $0.23 \mathrm{~g} \mathrm{(10} \mathrm{mmol)} \mathrm{sodium} \mathrm{in} 25 \mathrm{~cm}^{3}$ of dry methanol], $1.7 \mathrm{~g}$ (10 mmol) ethyl cyclohexanon-2-carboxylate and $2.4 \mathrm{~g}(10 \mathrm{mmol})$ $N$-(3'-benzyloxypropyl) thiourea (prepared according to Anders \& Jensen, 1958) was refluxed for $10 \mathrm{~h}$. The solvent was evaporated and residue was dissolved in $20 \mathrm{~cm}^{3}$ of water pyl)-5,6-tetramethylene-2-thio uracil in $5 \mathrm{~cm}^{3}$ $10 \%$ solution of chloroacetic acid was refluxed for $10 \mathrm{~h}$ to give $50 \%$ yield of $3-\mathrm{N}-\left(3^{\prime}\right.$-hydroxypropyl)-5,6-tetramethyleneuracil.

Analytical data of the synthesized acycyclonucleosides are shown in Table 1. Biologically active THI derivatives were synthesized by Brzezińska (1996) and analytical data of these compounds were described in the mentioned paper.

\section{Biology}

Chemical and enzyme assays. Tumours (5-6 g) obtained intraoperatively were immediately homogenized at $0^{\circ} \mathrm{C}$ in a Potter-Elvehjem apparatus in $20-24 \mathrm{ml}$ of $25 \mathrm{mM}$ Tris/HCl buffer ( $\mathrm{pH}$ 7.4) containing $250 \mathrm{mM}$ sucrose, $25 \mathrm{mM} \mathrm{KCl}$ and $5 \mathrm{mM} \mathrm{MgCl} 2$ (medium A). Nuclei and mitochondria were spun

Table 1. Analytical data of newly synthesized ACNs

\begin{tabular}{|c|c|c|c|c|c|c|c|c|c|c|c|c|c|c|c|}
\hline \multirow[b]{2}{*}{$\begin{array}{c}\text { Comp. } \\
1\end{array}$} & \multirow{2}{*}{$\begin{array}{l}\mathrm{mp} \\
{\left[\mathrm{C}^{\circ}\right]} \\
165\end{array}$} & $\begin{array}{l}\mathrm{TLC} \\
\mathrm{Rf} / \mathrm{S}_{2}\end{array}$ & \multicolumn{2}{|c|}{$\begin{array}{c}\text { UV } \lambda \max [\mathrm{mm}] \\
\varepsilon \times 10^{3}\end{array}$} & \multicolumn{6}{|c|}{ H1-NMR } & \multicolumn{5}{|c|}{ MS $[\mathrm{m} / \mathrm{e}] \%$} \\
\hline & & $\begin{array}{c}\mathrm{Rf} / \mathbf{S}_{2} \\
0.49\end{array}$ & $\begin{array}{l}\mathrm{pH} 7 \\
\frac{262}{8.5}\end{array}$ & $\begin{array}{c}\mathrm{pH} 13 \\
\frac{262}{6.5}\end{array}$ & $\begin{array}{l}\mathrm{N}-\mathrm{CH}_{2} \\
5.31 \mathrm{~s}\end{array}$ & $\begin{array}{l}\mathrm{N}_{3}-\mathrm{H} \\
8.94 \mathrm{bs}\end{array}$ & $\begin{array}{l}\mathrm{O}-\mathrm{CH}_{2} \\
3.52 \mathrm{t}\end{array}$ & $\begin{array}{c}\mathrm{C}-\mathrm{CH}_{2}-\mathrm{C} \\
1.59 \mathrm{~m}\end{array}$ & $\begin{array}{l}\mathrm{C}-\mathrm{CH}_{3} \\
0.90 \mathrm{t}\end{array}$ & $\begin{array}{c}\varnothing-\mathrm{CH}_{3} \\
2.35\end{array}$ & $\begin{array}{c}\mathrm{M}+ \\
\frac{198}{20.07}\end{array}$ & $\begin{array}{l}\text { M-43 } \\
\underline{155} \\
55.55\end{array}$ & $\begin{array}{c}\text { M-58 } \\
\frac{140}{62.48}\end{array}$ & $\begin{array}{l}\mathrm{B}+1 \\
\underline{126} \\
70.11\end{array}$ & $\begin{array}{r}43 \\
\underline{43} \\
100.0\end{array}$ \\
\hline
\end{tabular}

TLC silica gel $60 \mathrm{~F}_{254}, \mathrm{~S}_{2}, \mathrm{CHCl}_{3} / \mathrm{ETOH}(92: 8)$

\begin{tabular}{|c|c|c|c|c|c|c|c|c|c|c|c|c|c|c|c|}
\hline & $\mathrm{mp}$ & & & UV $\lambda \max$ & $\mathrm{lm}] \varepsilon \times 10^{3}$ & & $\mathrm{H1}$ & VMR & & & & MS & e] $\%$ & & \\
\hline $\begin{array}{c}\text { Comp. } \\
2\end{array}$ & $\begin{array}{l}\left.\mathrm{C}^{\circ}\right] \\
152\end{array}$ & $\begin{array}{c}\mathrm{S}_{1} \\
0.61\end{array}$ & $\begin{array}{c}\mathbf{S}_{2} \\
0.34\end{array}$ & $\begin{array}{c}\mathrm{pH} 7 \\
271 / 10.50\end{array}$ & $\begin{array}{c}\mathrm{pH} 13 \\
270 / 9.30\end{array}$ & $\begin{array}{l}\mathrm{N}-\mathrm{CH}_{2} \\
3.94 \mathrm{~m}\end{array}$ & $\begin{array}{l}\mathrm{O}-\mathrm{CH}_{2} \\
3.67 \mathrm{~m}\end{array}$ & $\begin{array}{c}\mathrm{C}-\mathrm{CH}_{2}-\mathrm{C} \\
1.65 \mathrm{~m}\end{array}$ & $\begin{array}{c}\mathrm{N}_{3}-\mathrm{H} \\
-\end{array}$ & $\begin{array}{c}\mathrm{M}+ \\
\frac{224}{62.14}\end{array}$ & $\begin{array}{c}M-18 \\
\frac{206}{24.86}\end{array}$ & $\begin{array}{c}\text { M-44 } \\
\frac{180}{33.06}\end{array}$ & $\begin{array}{l}\text { M-59 } \\
\frac{165}{47.80}\end{array}$ & $\begin{array}{l}\text { M-88 } \\
\frac{136}{60.18}\end{array}$ & $\begin{array}{c}\text { M-102 } \\
\frac{122}{32.94}\end{array}$ \\
\hline
\end{tabular}

\begin{tabular}{|c|c|c|c|c|c|c|c|c|c|c|c|c|c|c|c|}
\hline \multirow{2}{*}{ Comp. } & \multirow{2}{*}{$\begin{array}{c}\mathrm{mp} \\
{\left[\mathrm{C}^{\circ}\right]}\end{array}$} & \multicolumn{3}{|c|}{ Rf TLC } & \multicolumn{2}{|c|}{$\mathrm{UV} \lambda \max [\mathrm{nm}] \varepsilon \times 10^{3}$} & \multicolumn{4}{|c|}{ Hl-NMR } & \multicolumn{5}{|c|}{$\operatorname{MS}[\mathrm{m} / \mathrm{e}] \%$} \\
\hline & & $\mathrm{S}_{1}$ & $\mathrm{~S}_{2}$ & $\mathrm{~S}_{3}$ & $\mathrm{pH} 7$ & pH 13 & $\mathrm{~N}-\mathrm{CH}_{2}$ & $\mathrm{O}-\mathrm{CH}_{2}$ & $\mathrm{C}-\mathrm{CH}_{2}-\mathrm{C}$ & $\mathrm{N}_{1}-\mathrm{H}$ & $\mathrm{M}+$ & M-18 & M-44 & M-59 & M-88 \\
\hline 6 & $191-3$ & 0.60 & 0.50 & 0.67 & $270 / 8.92$ & $282 / 11.70$ & $4.10 \mathrm{t}$ & $3.52 \mathrm{t}$ & $1.75 \mathrm{~m}$ & $10.25 \mathrm{bs}$ & $\frac{224}{20.97}$ & $\frac{206}{32.92}$ & $\frac{180}{100.0}$ & $\frac{165}{57.43}$ & - \\
\hline 7 & $165-7$ & 0.71 & 0.72 & 0.81 & $283 / 8.30$ & $305 / 11.60$ & $4.56 \mathrm{t}$ & $3.58 \mathrm{t}$ & $1.71 \mathrm{~m}$ & $10.87 \mathrm{bs}$ & $\frac{240}{21.95}$ & $\frac{222}{8.69}$ & $\frac{196}{9.12}$ & $\frac{181}{18.63}$ & $\frac{207}{100.0}$ \\
\hline
\end{tabular}

TLC, Kiesel gel $60 \mathrm{~F}_{254}, \mathrm{~S}_{1}$, BuOH/ $\mathrm{H}_{2} \mathrm{O}$ (86: 14); $\mathrm{S}_{2}, \mathrm{CHCl}_{3} / \mathrm{EtOH}$, (92: 8); $\mathrm{S}_{3}, \mathrm{CH}_{3}-\mathrm{CO}_{-} \mathrm{CH}_{3}$; UV, Unicam SP 500; ${ }^{1} \mathrm{H}-\mathrm{NMR}$, Tesla $80 \mathrm{MHz}, \mathrm{CDCl}_{3}$; MS-direct inlet, LKB 6000, $70 \mathrm{eV}$.

and acidified with $30 \% \mathrm{H}_{2} \mathrm{SO}_{4}$. The precipitate was crystallized twice from ethanol, to give $60 \%$ yield of $3-\mathrm{N}-\left(3^{\prime}\right.$-hydroxypropyl)-5,6tetramethylene-2-thio uracil.

3-N-(3'-hydroxypropyl)-5, 6-tetramethyleneuracil (7): $0.48 \mathrm{~g}$ (2 mmol) 3- $\mathrm{N}$-(3'-hydroxypro- down at $10000 \times \boldsymbol{g}$ for $20 \mathrm{~min}$ and the resulting supernatant, after centrifugation at $105000 \times \boldsymbol{g}$ for $60 \mathrm{~min}$ representing the cytosol was used for the experiments. dThd and dCyd kinase activities were assayed as described previously (Greger \& Dramiński, 
1989), the phosphorylation of ACNs was performed under conditions optimal for dThd and dCyd kinase activities, using $0.2 \mathrm{mM}$ ACN or THI derivatives as a substrate and 10 $\mathrm{mM}\left[\gamma_{-}{ }^{32} \mathrm{P}\right] \mathrm{ATP}$ (0.02 MBq per sample) as a phosphate donor. The phosphorylation products were separated by TLC ascending chromatography (silica gel plates, Merck Kiselgel $60 \mathrm{~F}, 0.2 \mathrm{~mm}$ ) at room temperature in 1-propanol/conc. ammonia water (22:17, v/v), with $R_{\mathrm{f}}$ for ACN monophosphates 0.22 -0.24, ACN diphosphates 0.18-0.20, ACN triphosphates $0.02-0.05$ and spots corresponding to standards were counted in $5 \mathrm{ml}$ toluene scintillator. ACN phosphates used as does not catalyse THI phosphorylation, the radioactivity of chromatograms at $1 \mathrm{~cm}$ intervals (beginning with the starting position) was counted when investigating the THI phosphorylation catalyzed by the enzymes present in tumour cytosol. On the gel which was used for the separation of ACN phosphates, the accumulating ${ }^{32} \mathrm{P}$ of the lowest $R_{\mathrm{f}}$ corresponds to triphosphates. The isotope of higher $R_{\mathrm{f}}$ corresponds to diphosphates, and the one of the highest $R_{\mathrm{f}}-$ to monophosphates. Such a conclusion follows from the fact of chemical similarity of uracil ACN to THI. The enzyme activities and rates of ACN and THI phosphorylation were ex-

Table 2. The influence of biologically active ACNs (Fig. 1 comp. 1, 2) and THIs derivatives (Fig. 1 comp. 3,4 and 5) at $0.2 \mathrm{mM}$ concentration alone and in the presence of EDTA (10 mM) on dThd and dCyd kinase acitivities (U per mg of protein $\times 10^{-5}$ ) in the cytosol of neurofibrosarcoma (A) and ovarian cancer (B).

Each value: mean \pm S.D. for four separate experiments. $P$ values, after checking variance conformability using Fisher-Snedecor test, were calculated using Student's $t$-test. In parentheses \% of inhibition. NS, the difference non significant.

\begin{tabular}{|c|c|c|c|c|}
\hline $\begin{array}{l}\text { Compound } \\
\text { tested }\end{array}$ & $\begin{array}{c}\text { A } \\
\text { dThd kinase }\end{array}$ & $\begin{array}{c}\text { A } \\
\text { dCyd kinase }\end{array}$ & $\begin{array}{c}\text { B } \\
\text { dThd kinase } \\
\end{array}$ & $\begin{array}{c}\text { B } \\
\text { dCyd kinase } \\
\end{array}$ \\
\hline \multicolumn{2}{|c|}{ Control $11.2 \pm 1.7$} & $13.2 \pm 2.1$ & $10.1 \pm 1.6$ & $13.2 \pm 2.0$ \\
\hline 1 & $\begin{array}{l}7.0 \pm 1.0(37) \mathrm{K}_{\mathrm{i}} 7.9 \times 10^{-5} \mathrm{M} \\
P=0.002\end{array}$ & $\begin{array}{l}8.8 \pm 1.3(33) \mathrm{K}_{\mathrm{i}} 7.6 \times 10^{-5} \mathrm{M} \\
P=0.005\end{array}$ & $\begin{array}{l}6.6 \pm 1.0(34) \mathrm{K}_{\mathrm{i}} 1.1 \times 10^{-4} \mathrm{M} \\
P=0.005\end{array}$ & $\begin{array}{l}9.5 \pm 1.6(28) \mathrm{K}_{\mathrm{i}} 1.6 \times 10^{-5} \mathrm{M} \\
P=0.01\end{array}$ \\
\hline 1 plus EDTA & $10.8 \pm 1.6(4), \mathrm{NS}$ & $12.9 \pm 2.0(2), \mathrm{NS}$ & $9.8 \pm 1.4(3), \mathrm{NS}$ & $12.9 \pm 1.9(2), \mathrm{NS}$ \\
\hline $\begin{array}{c}2 \\
2 \text { plus EDTA }\end{array}$ & $\begin{array}{l}7.7 \pm 1.2(31), \mathrm{K}_{\mathrm{i}} 1.0 \times 10^{-4} \mathrm{M} \\
10.8 \pm 1.5(4), \mathrm{NS}\end{array}$ & $\begin{array}{l}7.8 \pm 1.3(41) \mathrm{K}_{\mathrm{i}} 5.6 \times 10^{-5} \mathrm{M} \\
12.8 \pm 20(3) \mathrm{NS}\end{array}$ & $\begin{array}{l}6.4 \pm 1.0(36), \mathrm{K}_{\mathrm{i}} 1.0 \times 10^{-4} \mathrm{M} \\
9.8 \pm 1.5(3) . \mathrm{NS}\end{array}$ & $\begin{array}{l}8.8 \pm 1.4(33) \mathrm{K}_{\mathrm{i}} 9.6 \times 10^{-5} \mathrm{M} \\
12.9 \pm 1.8(2) \mathrm{NS}\end{array}$ \\
\hline 3 & $\begin{array}{l}7.6 \pm 1.2(32), K_{i} 1.5 \times 10^{-4} \mathrm{M} \\
P=0.005\end{array}$ & $\begin{array}{l}9.6 \pm 1.5(27), K_{1} 1.2 \times 10^{-4} \mathrm{M} \\
P=0.02\end{array}$ & $10.2 \pm 1.6(0), \mathrm{NS}$ & $13.0 \pm 2.1(1), \mathrm{NS}$ \\
\hline 3 plus EDTA & $7.3 \pm 1.1(35)$ & $9.5 \pm 1.5(28), \mathrm{K}_{\mathrm{i}} 2.3 \times 10^{-4} \mathrm{M}$ & $9.5 \pm 1.4(5), \mathrm{NS}$ & $13.3 \pm 2.2(0), \mathrm{NS}$ \\
\hline 4 & $\begin{array}{l}7.3 \pm 1.2(35), \mathrm{K}_{\mathrm{i}} 1.8 \times 10^{-4} \mathrm{M} \\
P=0.005\end{array}$ & $12.4 \pm 1.8(6), \mathrm{NS}$ & $9.9 \pm 1.6(1), \mathrm{NS}$ & $12.1 \pm 1.7(8), \mathrm{NS}$ \\
\hline 4 plus EDTA & $7.2 \pm 1.2(36)$ & $13.3 \pm 2.0(0), \mathrm{NS}$ & $10.2 \pm 1.7(0), \mathrm{NS}$ & $12.5 \pm 1.8(5), \mathrm{NS}$ \\
\hline 5 & $\begin{array}{l}6.8 \pm 1.0(39), \mathrm{K}_{\mathrm{i}} 1.3 \times 10^{-4} \mathrm{M} \\
P=0.002\end{array}$ & $\begin{array}{l}8.9 \pm 1.3(33), \mathrm{K}_{i} 1.5 \times 10^{-4} \mathrm{M} \\
P=0.005\end{array}$ & $10.2 \pm 1.7(0), \mathrm{NS}$ & $12.1 \pm 1.6(8), \mathrm{NS}$ \\
\hline 5 plus EDTA & $7.0 \pm 1.0$ & $9.2 \pm 1.4(30), \mathrm{K}_{\mathrm{i}} 1.8 \times 10^{-4} \mathrm{M}$ & $9.9 \pm 2.0(1), \mathrm{NS}$ & $12.9 \pm 2.0(2), \mathrm{NS}$ \\
\hline 6 & $10.9 \pm 1.8(3), \mathrm{NS}$ & $12.7 \pm 1.9(4), \mathrm{NS}$ & $9.8 \pm 1.6(2), \mathrm{NS}$ & $12.5 \pm 1.8(5), \mathrm{NS}$ \\
\hline 6 plus EDTA & $10.7 \pm 1.6(5), \mathrm{NS}$ & $12.5 \pm 1.8(5), \mathrm{NS}$ & $9.5 \pm 1.4(5), \mathrm{NS}$ & $12.5 \pm 1.9(5), \mathrm{NS}$ \\
\hline 7 & $10.6 \pm 1.6(5), \mathrm{NS}$ & $12.5 \pm 1.9(5), \mathrm{NS}$ & $9.5 \pm 1.4(5), \mathrm{NS}$ & $12.6 \pm 1.7(4), \mathrm{NS}$ \\
\hline 7 plus EDTA & $10.7 \pm 1.8(5), \mathrm{NS}$ & $12.9 \pm 2.1(2), \mathrm{NS}$ & $10.7 \pm 1.8(4), \mathrm{NS}$ & $12.6 \pm 1.7(4), \mathrm{NS}$ \\
\hline
\end{tabular}

standards were obtained enzymatically using nucleoside phosphotransferase from Enterobacter agglomerans (Rutkowski \& Korczak, 1992) As the enzyme from this bacterium pressed as $\mu \mathrm{mol}$ of dNMP or dNTP formed per minute per milligram of protein $\times 10^{-5}$ (i.e. U per mg of protein $\times 10^{-5}$ ) $\left[{ }^{14} \mathrm{C}\right] \mathrm{dTTP}$ and $\left[{ }^{14} \mathrm{C}\right] \mathrm{dGTP}$ were assayed on acid soluble 
<smiles>Cc1cc(=O)[nH]c(=O)n1CCCO</smiles><smiles>Oc1cc2c(cc1O)C(c1cccc(Cl)c1Cl)NCC2</smiles>

4<smiles>O=c1c2c([nH]c(=S)n1CCCO)CCCC2</smiles><smiles>O=c1[nH]c(=O)n(CCCO)c2c1CCCC2</smiles>

2<smiles>Oc1cc2c(cc1O)C(c1ccc(Cl)cc1)NCCN2</smiles><smiles>COc1cccc(C2NCCc3cc(O)c(O)cc32)c1</smiles>

5<smiles>O=c1[nH]c2c(c(=O)n1CCCO)CCCC2</smiles>

\footnotetext{
1. 1-N-(3'hydroxypropyl)-6-methyluracil

2. 1-N-(3'hydroxypropyl)-5,6-tetramethyleneuracil

3. 1-(4-chlorophenyl)-6,7-dihydroxy-1,2,3,4-tetrahydroisoquinoline

4. 1-(2,3-dichlorophenyl)-6,7-dihydroxy-1,2,3,4-tetrahydroisoquinoline

5. 1-(3-methoxyphenyl)-6,7-dihydroxy-1,2,3,4-tetrahydroisoquinoline

6. 3-N-(3'hydroxypropyl)-2thio-5,6-tetramethyleneuracil

7. 3-N-(3'hydroxypropyl)-5,6-tetramethyleneuracil
}

Figure 1. Structural formulae of the active acyclonucleotides and 1,2,3,4-tetrahydroisoquinoline derivatives.

fraction obtained according to Letnansky (1964) from $20 \%(v / w)$ homogenates of neurofibrosarcoma and ovarian cancer in medium A enriched by $10 \mathrm{mM}$ ATP. After $1 \mathrm{~h}$ incubation with $\left[{ }^{14} \mathrm{C}\right] \mathrm{dTh}$ or $\left[{ }^{14} \mathrm{C}\right] \mathrm{dGuo}(0.02 \mathrm{MBq}$ per sample) the acid soluble fraction was passed through Dowex $1 \times 8$ (200-400 mesh, $0.8 \times 10 \mathrm{~cm}$ column) with standards (dTTP or dGTP) of concentration determined spectrophotometrically. Two-milliliter fractions were eluted from column with formic acid (Akyoshi, 1984) and fractions in which spectrophotometrically identified and determined added standards were counted in toluene scintillator (as above) containing $30 \%(\mathrm{v} / \mathrm{v})$ Triton X-100. DNA from both tumours was isolated and incorporation of $\left[{ }^{14} \mathrm{C}\right] \mathrm{dTh}$ and $\left[{ }^{14} \mathrm{C}\right] \mathrm{dGuo}$ into DNA was assayed according to the methods decribed by Blin \& Stafford (1976). Protein was determined by the Bradford method (1976). Statistical calculations were made using Fisher-Snedecor, Student's $t$-tests and a Sigma Plot 2001 for Windows version 7 computer program.

Tumour specimens were obtained from the Surgical Clinic of Oncology (neurofibrosarcoma), and from the Dept. of Gynecology and Gynecological Oncology, Med. Univ. of Łódź (ovarian cancer).

\section{RESULTS AND DISCUSSION}

Biologically active $0.2 \mathrm{mM}$ ACNs and THIs inhibit the synthesis of dTMP and dGMP to an identical level (ACN $34 \pm 4 \%$, THI $33 \pm$ 
$4.4 \%$ inhibition, Table 2) in the cytosol of neurofibrosarcoma (ACN, THI) and ovarian cancer (ACN). Active derivatives of THI (3, 4, 5 ) inhibit the activity of dThd and dCyd kinases only in the cytosol of neurofibrosarcoma, being inactive in the presence of the same enzymes in the cytosol of ovarian cancer. EDTA diminishes 12-fold the percentage of the inhi- bition of dTMP and dGMP synthesis by active ACNs while the inhibitory properties of active THI in the presence of EDTA remain unchanged. The differences in $K_{\mathrm{i}}$ values for ACN and THI (ACN $79 \pm 30 \mu \mathrm{M}$, THI $146 \pm 23$ $\mu \mathrm{M})$ point to different types of inhibition of dThd and dCyd kinase activity by ACN and THI.

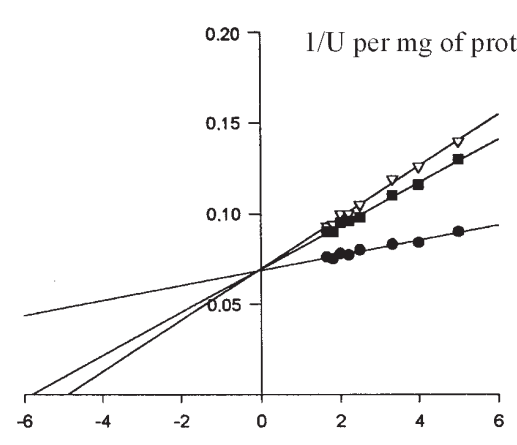

D

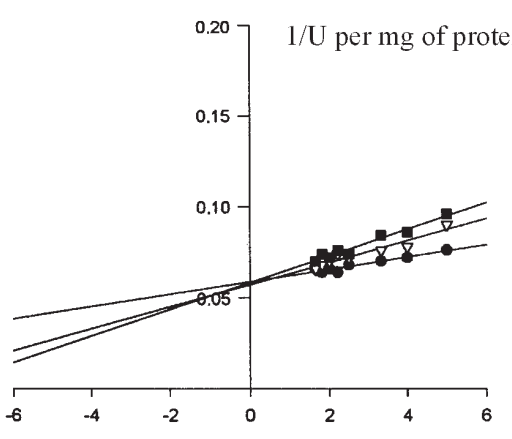

B

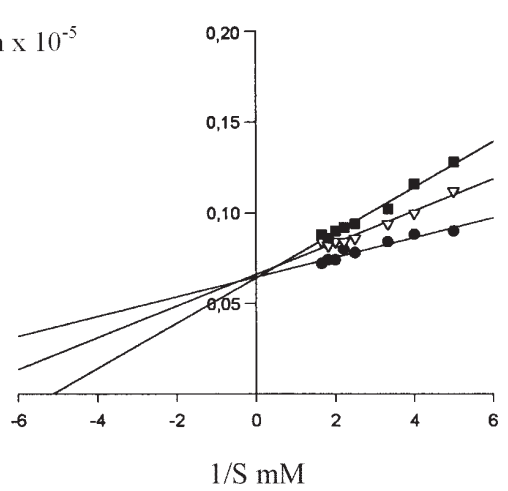

E

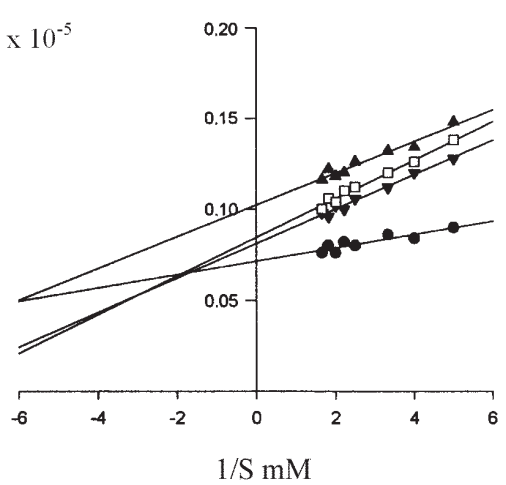

C
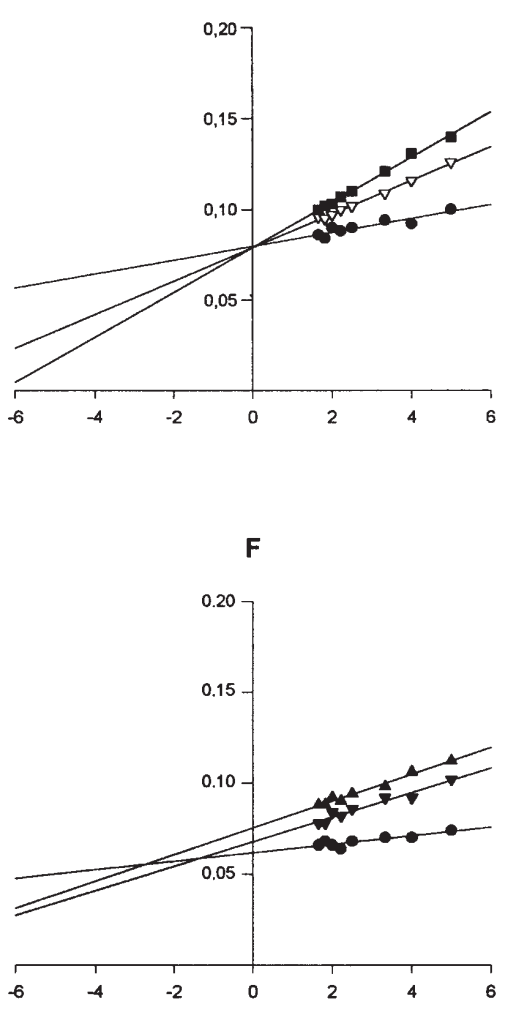

Figure 2. Lineweaver-Burk plots of dThd and dCyd kinase activities in cytosol of neurofibrosarcoma and ovarian cancer in the presence of $0.2 \mathrm{ACN} \mathrm{mM} \mathrm{(Fig.} \mathrm{1,} \mathrm{comp.} \mathrm{1,} \mathrm{2)} \mathrm{and} \mathrm{THI} \mathrm{(Fig.} \mathrm{1,} \mathrm{comp.} \mathrm{3,} \mathrm{4} \mathrm{and} \mathrm{5)}$ derivatives.

A, neurofibrosarcoma dThd kinase, $\left(\boldsymbol{\bullet}, \mathrm{r}^{2}=0.92\right)$, comp. $1\left(\nabla, \mathrm{r}^{2}=0.99\right)$, and $2\left(\mathbf{\square}, \mathrm{r}^{2}=0.98\right)$; $\mathbf{B}$, neurofibrosarcoma dCyd kinase, $\left(\mathbf{O}, \mathrm{r}^{2}=0.92\right)$, comp. $1\left(\nabla, \mathrm{r}^{2}=0.96\right)$, and $2\left(\mathbf{\square}, \mathrm{r}^{2}=0.97\right)$; C, ovarian cancer dThd kinase, $\left(\mathbf{\bullet}, \mathrm{r}^{2}=0.84\right)$, comp. $1\left(\nabla, \mathrm{r}^{2}=0.98\right)$, and $2\left(\mathbf{\square}, \mathrm{r}^{2}=0.99\right)$; $\mathbf{D}$, ovarian cancer dCyd kinase, $\left(\bullet, r^{2}=0.92\right)$, comp. $1\left(\nabla, r^{2}=0.91\right)$, and $2\left(\square, r^{2}=0.96\right) ; \mathbf{E}$, neurofibrosarcoma dThd kinase, $\left(\bullet, r^{2}=\right.$ $0.81)$, comp. $3\left(\boldsymbol{\nabla}, \mathrm{r}^{2}=0.97\right)$, comp. $4\left(\square, \mathrm{r}^{2}=0.97\right)$ and $5\left(\boldsymbol{\Delta}, \mathrm{r}^{2}=0.98\right)$; F, neurofibrosarcoma dCyd kinase, $\left(\boldsymbol{\bullet}, \mathrm{r}^{2}=0.78\right)$, comp. $3\left(\boldsymbol{\nabla}, \mathrm{r}^{2}=0.94\right)$, and $5\left(\boldsymbol{\Delta}, \mathrm{r}^{2}=0.94\right) . K_{\mathrm{m}}$ calculated from these plots equals: neurofibrosarcoma dThd kinase $51.2 \mu \mathrm{M}$, dCyd kinase $41.6 \mu \mathrm{M}$. Ovarian cancer: dThd kinase 53,7 $\mu \mathrm{M}$, dCyd kinase $71,4 \mu \mathrm{M} . K_{\mathrm{mi}}$ values calculated from these plots are: neurofibrosarcoma dThd kinase comp. 1, 2, 3, 4 and 5: 1.8, 1.5, 1.2, 1.07, $1.3 \times 10^{-4} \mathrm{M}$, respectively; dCyd kinase comp. 1, 2, 3 and 5: 1.5, 1.9, 1.1 $\times 10^{-4} \mathrm{M}, 9.6 \times 10^{-5} \mathrm{M}$, respectively. Ovarian cancer dThd kinase, comp. 1 and $2: 1.5,1.6 \times 10^{-4} \mathrm{M}$ respectively; dCyd kinase, comp. 1 and 2: $9.8,1.2 \times 10^{-4} \mathrm{M}$, respectively. $K_{\mathrm{i}}$ values included in Table 2 were obtained from these $K_{\mathrm{mi}}$ values; $\mathrm{r}^{2}>0.5$ indicates a high positive linear correlation coefficient (according to Sigma Plot 2001 for Windows version 7 statistical computer program). 
Figure 2 demonstrates the course of activity of dThd kinase from neurofibrosarcoma at increasing substrate concentrations without and in the presence of $0.2 \mathrm{mM}$ active ACNs 1 and 2 (Table 2) as well as active THIs 3,4 and 5 . Changes in the enzyme activity in the presence of ACN derivatives point to a competitive type of inhibition of the enzyme by these compounds, while THI derivatives inhibit the enzyme in a mixed way. The inhibition of dGMP synthesis by active THI derivatives 3 and 5 in neurofibrosarcoma (Table 2) is also of a mixed character. This fact may be explained by a greater $K_{\mathrm{i}}$ value for THI where, unlike in competitive inhibition, the inhibitor binds both the free enzyme as well as the enzyme-substrate complex. Table 2 comprises aditionally a set of characteristics of two ACN derivatives 6 and 7. They exhibit only $5 \%$ of the activity of compounds 1 and 2, but they were subsequently used for the explanation of active ACNs biotransformation.

A loss of the inhibitory properties of ACN derivatives 1 and 2 in the presence of EDTA and a complete lack of this effect in the presence of ACN derivatives 6 and 7 and THI derivatives 3,4 and 5 suggest a possibly different ACN and THI metabolism. This suggestion is confirmed by the results of ACN and THI phosphorylation presented in Table 3. Biologically active ACNs undergo phosphorylation to corresponding triphosphates by deoxynucleoside 5'-mono and 5'-diphosphate kinases present in the cytosol of both tumours. The extent of phosphorylation to the corresponding triphosphates of derivatives 1 , 2, 6 and 7 is the same but the resulting amounts of ACN triphosphates of derivatives 6 and 7 is 20-fold lower than triphosphate derivatives 1 and 2 . Both the above mentioned facts and the almost complete lack of inhibitory activity of derivatives 6 and 7 (Table 2) allow one to presume that ACN triphosphates are the inhibitors of dThd and dCyd kinases in neurofibrosarcoma and ovarian cancer. Another confirmation of this inference is the behaviour of active ACNs in the presence of
EDTA. While inhibiting the activity of deoxynucleoside 5'-diphosphates kinase (Buczyński \& Potter, 1990) EDTA, at the same time, inhibits the synthesis of ACN triphosphates which explains the almost complete loss of inhibitory properties of active ACNs (Table 2) 1 and 2. Active THI derivatives 3,4 and 5 are not phosphorylated by the enzyme present in the tumour cytosol since they are not substrates for kinases. The $\mathrm{OH}$ groups present in the aromatic structure of THI are of acidic character, therefore, they cannot form esters with $\mathrm{HPO}_{4}{ }^{2-}$. For this reason EDTA exerts no influence on the inhibitory properties of THI derivatives.

Although the biological activity of modified nucleosides and nucleotides usually results from in vivo phosphorylation of these compounds (Parker et al., 1995; Ilsley et al., 1995; Modrzejewska et al., 1999) some biologically active nucleosides inhibiting HIV-1 are not phosphorylated in vivo (Fossey et al., 1994). Similarly, alkenophosphonic acid purine and pyrimidine derivatives acting as ACN triphosphate equivalents do not themselves undergo phosphorylation (Harnden et al., 1993). Active THI derivatives, therefore, should be included among the compounds whose biological activity does not result from phosphorylation.

While commenting on the results included in Table 3 it should be noticed that the $\mathrm{CH}_{2} \mathrm{OH}$ group, preferred by cellular kinases (Daher et al., 1990) which is a component of the 3-hydroxypropyl group of the studied ACNs 1, 2, 6 and 7 (Fig. 1) is a substrate for these enzymes only when it is bound to the position $\mathrm{N}-1$ of the modified pyrimidine base 1 and 2 (Fig. 1). The above mentioned group present in the 3-hydroxypropyl group bound to N-3 position of modified pyrimidine bases 6 and 7 (Fig. 1) is not recognized by cellular kinases. This explains the very low phosphorylation of ACN derivatives 6 and 7 and, as a consequence, the almost complete lack of inhibitory activity of these compounds (Table 2 and 3). 
Table 3. Phosphorylation of ACNs and THIs (0.2 mM) catalysed by kinases present in the cytosol of neurofibrosarcoma (A) and ovarian cancer (B) ( $\mu$ mol of $\left[{ }^{32}\right.$ P]ACN or $\left[{ }^{32}\right.$ P]THI mono-, di-, and triphosphate formed per min per $\mathrm{mg}$ of protein $\times 10^{-5}$ ).

The active ACNs (alone or in presence of $10 \mathrm{mM}$ EDTA) and THIs were incubated per $1 \mathrm{~h}$ with the cytosol obtained from tumours in the presence of $10 \mathrm{mM}\left[\gamma_{-}{ }^{32} \mathrm{P}\right] \mathrm{ATP}(0.02 \mathrm{MBq}$ per sample) and counted as described in Materials and Methods. ACNs phosphorylation proceeds to function $y=f(x)$, were $x$ is a straight line following $y=a x+b$ equetion and the increase ACN phosphates concentration is a linear time function. In parentheses: \% of phosphorylation. Each value: the mean \pm S.D. for five separate experiments. Compound number according to Fig. 1.

\begin{tabular}{|c|c|c|c|c|c|c|c|c|}
\hline \multirow[b]{2}{*}{$\begin{array}{l}\text { Compound } \\
\text { tested }\end{array}$} & \multicolumn{4}{|c|}{$\mathrm{A}$} & \multicolumn{4}{|c|}{ B } \\
\hline & $\begin{array}{l}\left.{ }^{32} \mathrm{P}\right] \mathrm{mono} \mathrm{-}^{-} \\
\text {phosphate }\end{array}$ & {$\left[{ }^{32} \mathrm{P}\right]$ diphosphate } & {$\left[{ }^{32} \mathrm{P}\right]$ triphosphate } & $\begin{array}{c}\text { sum of } \\
\text { phosphoryla } \\
\text { tion }\end{array}$ & $\begin{array}{l}\left.{ }^{32} \mathrm{P}\right] \text { mono- } \\
\text { phosphate }\end{array}$ & {$\left[{ }^{32} \mathrm{P}\right]$ diphosphate } & {$\left[{ }^{32} \mathrm{P}\right]$ triphosphate } & $\begin{array}{c}\text { sum of } \\
\text { phosphoryla } \\
\text { tion }\end{array}$ \\
\hline 1 & $4.1 \pm 0.8(84)$ & $0.41 \pm 0.08(8.4)$ & $0.34 \pm 0.07(7)$ & 4.85 & $3.9 \pm 0.7(85)$ & $0.36 \pm 0.08(7.9)$ & $0.3 \pm 0.05(6.6)$ & 4.56 \\
\hline 1 plus EDTA & $0.23 \pm 0.03(91)$ & $0.022 \pm 0.003(8.7)$ & 0.00 & 0.252 & $0.24 \pm 0.04(91)$ & $0.022 \pm 0.004(8.4)$ & 0.00 & 0.29 \\
\hline 2 & $4.4 \pm 0.8(87)$ & $0.36 \pm 0.06(7.1)$ & $0.31 \pm 0.05(6)$ & 5.07 & $3.8 \pm 0.7(86)$ & $0.32 \pm 0.05(7.2)$ & $0.29 \pm 0.05(6.6)$ & 4.41 \\
\hline 2 plus EDTA & $0.28 \pm 0.04(92)$ & $0.023 \pm 0.003(7.5)$ & 0.00 & 0.303 & $0.25 \pm 0.04(93)$ & $0.018 \pm 0.002(6.9)$ & 0.00 & 0.268 \\
\hline 3 & 0.00 & 0.00 & 0.00 & 0.00 & 0.00 & 0.00 & 0.00 & 0.00 \\
\hline 4 & 0.00 & 0.00 & 0.00 & 0.00 & 0.00 & 0.00 & 0.00 & 0.00 \\
\hline 5 & 0.00 & 0.00 & 0.00 & 0.00 & 0.00 & 0.00 & 0.00 & 0.00 \\
\hline 6 & $0.3 \pm 0.05(86)$ & $0.028 \pm 0.004(8.0)$ & $0.02 \pm 0.003(5.7)$ & 0.348 & $0.27 \pm 0.04(85)$ & $0.028 \pm 0.004(8.8)$ & $0.02 \pm 0.003(6.3)$ & 0.318 \\
\hline 7 & $0.27 \pm 0.05$ & $0.02 \pm 0.003(6.5)$ & $0.016 \pm 0.003(5.2)$ & 0.306 & $0.24 \pm 0.04$ & $0.03 \pm 0.004(10)$ & $0.016 \pm 0.002(5.6)$ & 0.286 \\
\hline
\end{tabular}

Active ACNs and THIs decrease the synthesis of dTTP and dGTP in the acid soluble fraction of both tumours (Table 3, ACN derivatives: $41.5 \pm 5.2 \%$, THI derivatives: $47.2 \pm$ $3.7 \%$ of synthesis inhibition, respectively). In the case of THI this concerns only these derivatives which inhibit the activity of dThd and dCyd kinases in the cytosol of neurofibro- sarcoma. The THI derivatives without such activity have no influence on the content of dTTP and dGTP in the acid soluble fraction of both tumours. Incubation of $\left[{ }^{14} \mathrm{C}\right] \mathrm{dN}$ in the presence of ACN decrease dTTP and dGTP synthesis by, on average, $42 \%$, as a consequence of inhibition by ACN triphosphates formed. THI derivatives which inhibit dTMP

Table 4. Synthesis of $\left[{ }^{14} \mathrm{C}\right] \mathrm{dTTP}$ and $\left[{ }^{14} \mathrm{C}\right] \mathrm{dGTP}$ in neurofibrosarcoma (A) and ovarian cancer (B) as a result of $1 \mathrm{~h}$ incubation of $\left[{ }^{14} \mathrm{C}\right] \mathrm{dTh}$ or $\left[{ }^{14} \mathrm{C}\right] \mathrm{dGu}$ with $20 \%(\mathrm{v} / \mathrm{w})$ tumor homogenates in medium $\mathrm{A}$ (containing additionally $10 \mathrm{mM}$ ATP) with active ACNs (Fig. 1 comp. 1, 2) and THIs (Fig. 1 comp. 3, 4 and 5) alone or in the presence of $10 \mathrm{mM}$ EDTA.

$\left[{ }^{14} \mathrm{C}\right] \mathrm{dTTP}$ or $\left[{ }^{14} \mathrm{C}\right] \mathrm{dGTP}$ were isolated from acid soluble fraction and counted (expressed in nmol per mg of tumour wet weight, for the detail see Materials and Methods). Each value: mean \pm S.D. for five separate experiments. $p$ value was counted as in Table 2 . In parentheses: \% of synthesis inhibition, NS, the difference non significant.

\begin{tabular}{|c|c|c|c|c|}
\hline & & A & & \\
\hline 1 & $6.7 \pm 1.1(46), P=0.002$ & $8.5 \pm 1.5(40), P=0.005$ & $4.2 \pm 0.6(38), P=0.005$ & $8.8 \pm 1.4(52), P=0.005$ \\
\hline 2 & $7.4 \pm 1.3(40), P=0.005$ & $9.0 \pm 1.6(36), P=0.01$ & $4.0 \pm 0.6(42), P=0.005$ & $9.4 \pm 1.5(38), P=0.005$ \\
\hline 4 & $6.7 \pm 1.2(46), P=0.005$ & $12.7 \pm 2.0(10), \mathrm{NS}$ & $5.4 \pm 0.9(22), \mathrm{NS}$ & $12.4 \pm 2.2(18), \mathrm{NS}$ \\
\hline 5 & $7.2 \pm 1.3(42), P=0.005$ & $7.2 \pm 1.2$ (49), $P=0.001$ & $6.3 \pm 1.2(8), \mathrm{NS}$ & $14.3 \pm 2.4(6), \mathrm{NS}$ \\
\hline 1 plus EDTA & $10.6 \pm 1.9(14), \mathrm{NS}$ & $11.5 \pm 1.9(18), \mathrm{NS}$ & $5.5 \pm 0.9(20), \mathrm{NS}$ & $12.0 \pm 2.0(21), \mathrm{NS}$ \\
\hline
\end{tabular}


and dGMP synthesis, in the presence of EDTA decrease dTTP and dGTP level by, on average, $48 \%$. This may follow from the fact that EDTA restrains the activity of the deoxynucleoside $5^{\prime}$-diphosphate kinase but not inhibition of phosphorylation of THI as these compounds are not phosphorylated by the enzyme present in the tumour homogenate. This finding is also confirmed by the fact that EDTA inhibits the synthesis of dTTP and dGTP to the same degree in the presence of biologically inactive THI.

In previous studies on uracil ACN derivatives it was proved that uracil alliloxymethyl derivatives, beside moderating the synthesis of DNA precursors, inhibit the in vivo incorporation of labeled $\mathrm{dN}$ into DNA obtained from experimental tumours (Greger \& Dramiński, 1989; Modrzejewska et al., 1996; 1999). Similar studies which were carried out synthesis, diminishing, as a consequence, the synthesis of dTTP and dGTP (on average 50.5 $\pm 2.7 \%$ of incorporation inhibition) being substrates for DNA polymerase. For the same reasons THI derivatives which inhibit dTMP and dGMP synthesis decrease the incorporation of $\left[{ }^{14} \mathrm{C}\right] \mathrm{dTh}$ and $\left[{ }^{14} \mathrm{C}\right] \mathrm{dGuo}$ into DNA (on average $53.4 \pm 4.0 \%$ of incorporation inhibition). As was explained, while commenting on results of Table 4 , the decrease of $\left[{ }^{14} \mathrm{C}\right] \mathrm{dN}$ incorporation into DNA of the tumours by on average $92 \%$ of incorporation inhibition in the presence of ACN and EDTA is a consequence of inhibition of ACN triphosphate syntesis by EDTA. Although THI derivatives in the presence of EDTA decrease the incorporation of $\left[{ }^{14} \mathrm{C}\right] \mathrm{dN}$ into DNA $(58 \pm 5.2 \%$ of incorporation inhibition) this is a result of decreased concentration of dTTP and dGTP and not the effect of EDTA on THI.

Table 5. Incorporation of $\left[{ }^{14} \mathrm{C}\right] \mathrm{dTh}$ Thd $\left[{ }^{14} \mathrm{C}\right] \mathrm{dGuo}(0.02 \mathrm{MBq})$ into DNA obtained from $20 \%$ homogenate (v/w) in medium A of neurofibrosarcoma (A) and ovarian cancer (B).

$\left[{ }^{14} \mathrm{C}\right] \mathrm{dN}$ were incubated separately for $1 \mathrm{~h}$ with homogenates of tumours with active ACNs and THIs (0.2 mM, Fig. 1 comp. 1, 2, 3, 4, and 5) alone or in the presence of $10 \mathrm{mM}$ EDTA. The DNA was isolated from homogenates and incorporation was expressed in nmol of $\left[{ }^{14} \mathrm{C}\right] \mathrm{dN}$ per mg of DNA (for details see Materials and Methods). Each value: the mean \pm S.D. for four separate experiments. In parentheses: $\%$ of incorporation inhibition. NS, the difference non significant.

\begin{tabular}{|c|c|c|c|c|}
\hline \multirow{2}{*}{$\begin{array}{l}\text { Compound } \\
\text { tested }\end{array}$} & \multicolumn{2}{|l|}{ A } & \multicolumn{2}{|c|}{ B } \\
\hline & dThd & dGuo & dThd & dGuo \\
\hline Control & $24.2 \pm 4.1$ & $33.6 \pm 5.8$ & $18.4 \pm 3.0$ & $38.3 \pm 6.5$ \\
\hline 1 & $11.1 \pm 1.7(54), P=0.002$ & $15.8 \pm 2.7(53), P=0.002$ & $9.9 \pm 1.8(46), P=0.005$ & $18.0 \pm 3.0(53), P=0.002$ \\
\hline 2 & $12.1 \pm 2.0(50), P=0.002$ & $16.5 \pm 2.8(51), P=0.002$ & $9.4 \pm 1.7(49), P=0.005$ & $19.9 \pm 3.4(48), P=0.005$ \\
\hline 3 & $11.2 \pm 1.8(54), P=0.002$ & $13.8 \pm 2.2(59), P=0.001$ & $14.0 \pm 2.3(24), \mathrm{NS}$ & $30.2 \pm 4.8(21), \mathrm{NS}$ \\
\hline 4 & $12.5 \pm 2.1(48), P=0.005$ & $29.5 \pm 5.0(12), \mathrm{NS}$ & $14.7 \pm 2.5(20), \mathrm{NS}$ & $31.8 \pm 5.2(17), \mathrm{NS}$ \\
\hline 5 & $11.7 \pm 1.9(52), P=0.002$ & $15.4 \pm 2.5(54), P=0.002$ & $15.1 \pm 2.7(18), \mathrm{NS}$ & $34.5 \pm 6.1(10), \mathrm{NS}$ \\
\hline 1 plus EDTA & $1.84 \pm 0.33(92), P=0.001$ & $2.62 \pm 0.44(92), P=0.001$ & $1.51 \pm 0.3(92), P=0.001$ & $3.1 \pm 0.6(92), P=0.001$ \\
\hline 2 plus EDTA & $1.88 \pm 0.35(92), P=0.001$ & $2.82 \pm 0.49(92), P=0.001$ & $1.4 \pm 0.25(92), P=0.001$ & $3.0 \pm 0.6(92), P=0.001$ \\
\hline 3 plus EDTA & $9.2 \pm 1.5(62), P=0.001$ & $13.4 \pm 2.2(60), P=0.001$ & $8.5 \pm 1.4(54), P=0.001$ & $20.0 \pm 3.4(58), P=0.005$ \\
\hline 4 plus EDTA & $8.7 \pm 1.4(64), P=0.001$ & $14.1 \pm 2.5(58), P=0.001$ & $9.4 \pm 1.6(49), P=0.002$ & $19.1 \pm 3.2(50), P=0.002$ \\
\hline 5 plus EDTA & $8.2 \pm 1.3(66), P=0.001$ & $12.4 \pm 1.9(63), P=0.001$ & $7.5 \pm 1.2(60), P=0.001$ & $15.7 \pm 2.8(59), P=0.001$ \\
\hline
\end{tabular}

on ACNs and THIs demonstrated that these compounds possess similar inhibitory properties. The results of these experiments (Table 5) confirm the conclusions which follow from the data included in Tables 2-4. The incorporation of $\left[{ }^{14} \mathrm{C}\right] \mathrm{dTh}$ and $\left[{ }^{14} \mathrm{C}\right] \mathrm{dGuo}$ into DNA of both tumours is inhibited by these ACN derivatives which restrain dTMP and dGMP
The inhibition of the activity of dThd and dCyd kinases by uracil ACN derivatives, i.e. inhibition of pyrimidine nucleoside kinases by pyrimidine acyclonucleosides might have been expected. It is not surprising that THI derivatives reveal similar properties as being benzene rings condensed with tertahydropyridine they are formally similar to the ACN 
derivatives of tetramethylene uracil 2, 6 and 7 (Fig. 1). Recently several papers have been published which present an extension of THI biological activity spectrum. And so THI derivatives may produce parkinsonism in experimental animals (Abe et al., 2001) damage DNA (Jung \& Surh, 2001) participate in the regulation of methyltransferase activity in metabolism of catecholamines (Kawai et al., 2000) or inhibit the binding of cGMP by respective phosphodiesterase (Kotera et al., 2000).

The results of the present paper revealing novel inhibitory properties of THIs towards $\mathrm{dN}$ kinases will contribute to a search for further THI derivatives which will be better inhibitors of DNA component synthesis than those already described.

\section{R E F E R E N C E S}

Abe K, Taguchi K, Wasai T, Ren J, Utsunomiya I, Shinohara T, Miyatake T, Sano T. (2001) Biochemical and pathological study of endogenous 1-benzyl-1,2,3,4-tetrahydroisoquinoline induced parkinsonism in the mouse. Brain Res.; 907: 134-8.

Akyoshi H. (1984) Formation of deoxynucleoside 5 '-monophosphate dependent on DNA synthesis in nuclei isolated from regenerating rat liver. Biochim Biophys Acta.; 782: $142-6$.

Anders K, Jensen RB. (1958) Isothiocyanates XXXII. Synthesis and reactions of 3-benzyloxypropyl isothiocyanate, enzymatically liberated from glucomalcolmin and some compounds of related structure. Acta Chem Scand.; 12: 1746-58.

Arner AES, Eriksson S. (1995) Mammalian deoxynucleoside kinase. Pharm Ther.; 67: 155-186.

Blin N, Stafford DW. (1976) General methods for isolation of high molecular DNA from eucariotes. Nucleic Acids Res.; 3: 2303-8.

Bradford MM. (1976) A rapid and sensitive method for the quantitation of microgram quantities of protein utilizing the principle of protein-dye binding. Anal Biochem.; 72: 248-54.

Brzezińska E. (1996) Synthesis and pharmacological properties of 6,7-dimethoxy-1,2,3,4-tetrahydroisoquinoline. Acta Pol Pharm.; 53: 365-71.

Buczyński B, Potter RL. (1990) Nucleoside diphosphate kinase from Xenopus oocytes: partial purification and characterisation. Biochim Biophys Acta.; 1041: 296-304.

Daher GC, Harris BE, Diasio R. (1990) Metabolism of pyrimidine analogues and their nucleosides. Pharm Ther.; 48: 189-222.

Fossey C, Laduerre D, Robba A. (1994) Synthesis of acyclic thiens [3,2-d] pyrimidine nucleosides and azido derivatives as potential anti-HIV agents. Nucleosides \& Nucleotides.; 13: $883-9$.

Goldbrunner M, Loidl G, Polossek T, Mannschreck A, Auger E. (1997) Inhibition of tubulin polymerization by 5,6-dihydro[21-a] isoquinoline derivatives. $J$ Med Chem.; 40: 3524-33.

Greger J, Dramiński M. (1989) Growth inhibition of Kirkman-Robbins hepatoma by 1(1', $3^{\prime}$-dihydroxy-2'-propoxymethyl)-5,6-tetra methyleneuracil and possible mechanism of its biological activity. $Z$ Naturforsch.; 44c: 985-91.

Harnden MR, Parkin A, Parratt MJ, Perkins RM. (1993) Novel acyclonucleosides: synthesis and antiviral activity of alkenylphosphonic acid derivatives of purine and pyrimidine. J Med Chem.; 36: 1343-55.

Ilsley DD, Lee S-H, Miller WH, Kuchta RD. (1995) A cyclic guanosine analogs inhibit DNA polymerase $\alpha, \delta$ and $\varepsilon$ with very different potenties and have unique mechanism of action. Biochemistry.; 34: 2504-10.

Jullig M, Eriksson S. (2001) Apoptosis induced efflux of the mitochondrial matrix enzyme deoxyguanosine kinase. J Biol Chem.; 276: 24000-4.

Jung Y, Surh Y. (2001) Oxidative DNA damage and cytotoxicity induced copper stimulated redox cycling of salsolinol, a neurotoxic 
tetrahydroisoquinoline alkaloid. Free Rad Biol Med.; 30: 1407-17.

Kawai H, Kotake Y, Ohta S. (2000) Dopamine transporter and catechol-O-methyltransferase activities are required for the toxicity of 1-(3',4'-dihydroxybenzyl)-1,2,3,4-tertahydroisoquinoline. Chem Res Toxicol.; 13: 1294-301.

Kotera J, Fujishige K, Michibata H, Yuasa K, Kubo A, Nakamura Y, Omori K. (2000) Characterisation and effects on methyl-2-(4-aminophenyl)-1,2-dihydro-1-oxo7-(2-pyridynylmethoxy)-4-(3,4,5-trimethoxyphenyl)-3-isoquinoline carboxylate sulfate. (T-1032) a novel potent inhibitor of cGMP-binding cGMP specific phosphodiesterase. Biochem Pharm.; 60: 1333-41.

Letnansky K. (1964) The influence of 2-deoxy-D-glucose on the nucleotide content of Ehrlich ascites carcinoma cells. Biochim Biophys Acta.; 87: 1-8.

Lin M-C, Shun T-S, Penketh P, Sartorelli A. (1995) Synthesis and antitumor activity of 4 and 5 substituted derivatives of isoquinoline-1-carboxyaldehyde-thio-semicarbasone. J Med Chem.; 38: 4234-45.

Modrzejewska H, Greger J, Dramiński M, Rutkowski M. (1996) The influence of alkoxymethyl purine and pyrimidine acyclonucleosides on growth inhibition of Kirkman-Robbins hepatoma and possible mechanism of their cytostatic activity. $Z$ Naturforsch.; 51c: $75-80$.

Modrzejewska H, Dramiński M, ZgitWróblewska A, Greger J. (1999) Further studies on cytostatic activity of alkoxymethyl purine and pyrimidine acyclonucleosides. $Z$ Naturforsch.; 54c: 923-31.

Parker WB, Shaddix SC, Rose LM, Taiwari KN, Mongomery JA, Secrist III JA, Benett LL Jr. (1995) Metabolism and metabolic action of 4-thiothymidine in L 1210 cells. Biochem Pharmacol.; 50: 687-95.

Rutkowski M, Korczak E. (1992) Biotransformation by Enterobacter agglomerans of pyrimidine acyclonucleosides to acyclonucleotides. Experientia.; 48: 600-3.

Usova E, Eriksson S. (1997) The effects of high salt concentration on the regulation of the substrate specificity of human recombinant deoxycytidine kinase. Eur J Biochem.; 248: $762-6$.

Wang L, Karlsson A, Arner ESJ, Eriksson S. (1993) Substrate specificity of mitochondrial 2 '-deoxyguanosine kinase. $J$ Biol Chem.; 268: $22847-52$. 